\title{
Obsolescent Reformed Libraries in the SEVEnteenth AND eighteenth Century Carpathian Basin ${ }^{1}$
}

\section{Róbert Oláh}

The varying composition of library stocks can easily be grasped if we concentrate on the latest publications or new trends such as Cartesianism, or the authors of the Enlightenment during the course of research. ${ }^{2}$ Furthermore, the question, i.e., how the appearance and rate of former publications can be evaluated? is just as exciting. The aim of my paper is to draw attention to the phenomenon of obsolence that used to be one of the most significant characteristics of Reformed institutional and private libraries in the $17^{\text {th }}$ and $18^{\text {th }}$ century Carpathian Basin.

\section{BOOK-TRADE AND CENSORSHIP}

In early modern Hungary book-trade could be defined as the activity of printers, hucksters and other foreign cheap jacks. Printers were selling publications printed by themselves or those on trust. Even $18^{\text {th }}$ century book collections were augmented by mediaeval methods. The lack of organised book-trade did not automatically lead to isolation. Hungarian intellectuals were able to remain up-to-date by the acquisition of books until the early $17^{\text {th }}$ century owing to one of the "side effects" of peregrination. Examining sources from the second half of the $17^{\text {th }}$ and the beginning of the $18^{\text {th }}$ centuries, it can be verified that a higher and higher proportion of

1 This paper has been completed by the support of the Scholarship 'István Szegedi Kis' of the Ministry of Human Capacities (Hungary).

2 See: Monok István, Descartes-recepció a Kárpát-medence olvasmánytörténeti forrásainak tükrében, 1660-1740 = A kartezianizmus négyszáz éve, Szeged, Pro Philosophia Szegediensi Alapítvány, 1996 (Ész, élet, egzisztencia, 5), 297-305; Hegri Ádám, „... azt kőzőnséges helyen fel olvasni éppen nem tanátsos...”: Az olvasás és a vallásellenesség kapcsolatai a Békés-(Bánáti) Református Egyházmegyében 1781 és 1821 között, Debrecen, TtRE Gyűjtemények, 2018 (Tiszántúli Református Egyházkerületi Gyűjtemények kiadványai). 
volumes from Western Europe were earlier editions. This backwardness cannot be explained by the limited possibilities of book-trade either. ${ }^{3}$

The lack of Protestant universities in the Carpathian Basin resulted in students of the Augustan and Helvetic confessions gaining university education abroad until the second half of the $19^{\text {th }}$ century. The direction and intensity of peregrination was changing due to historical events. Between the $16^{\text {th }}$ and $18^{\text {th }}$ centuries Reformed students who firstly attended universities in Germany (Wittenberg, Heidelberg, Frankfurt an der Oder, Leipzig, Jena), The Netherlands (Leiden, Utrecht, Franeker, Groningen, Harderwijk), Switzerland (Zürich, Basel, Genf) and England (Oxford, Cambridge) ${ }^{4}$ brought a significant number of books from abroad both for themselves, their patrons (noblemen, citizens of country towns), and their former schools.

For a long time authorities did not interfere much with their activity. This could partly have resulted from the fact that they circumvented the alertness of German and Austrian Catholic provinces and that of Hungarian authorities. In February 1607 István Miskolci Csulyak, who was on his way from Heidelberg to Hungary, wrote a letter to his friend Albert Szenci Molnár asking him to get the books, which were packed in two barrels, home from Frankfurt to make them appear "as if they were not books". ${ }^{5}$ It was a good solution to evade the Habsburg provinces and direct them towards Poland. Peregrinating students who were going to The Netherlands to study at Dutch universities often chose this route. After his studies in Leiden, Franeker, Groningen and Utrecht

3 Момок István, Mitôl modern egy kora újkori könyvtár Magyarországon és Erdélyben? = Hagyomány, egység és korszerúség: az Egyházi Könyvtárak Egyesülése 2009. november 10-i jubileumi konferenciájának előadásai, szerk. GÁBORJÁNI Szabó Botond, Debrecen, Egyházi Könyvtárak Egyesülése, 2010, 20-2l.

4 See: TAmusné Molnár Viktória, Debreceni peregrinusok a 16-19. században, Magiszter, 2011/2, 88-99; SzöGi László, A magyar protestáns peregrináció a 16-18. században, Gerundium, 2017/1, 71-78.

5 Pécseli Király Imre, Miskolczi Csulyak István és Nyéki Vörös Mátyás versei, sajtó alá rend. Jenei Ferenc, Klaniczay Tibor, Kovács József, Stoli Béla, Budapest, Akadémiai, 1962 (Régi magyar költők tára, XVII. század, 2), 290, 317. 
e.g. Miklós Apáti Madár returned home through Poland. It was he who together with János Bánki escorted the volumes of the Hungarian Bible with great difficulty on their way to Hungary. ${ }^{6}$ The Bibles were printed in Amsterdam by Miklós Tótfalusi Kis. ${ }^{7}$

A primary source from 1655 testifies that the books of a Protestant student, who was returning to Hungary, were confiscated at the border. This case was so unusual that both Pozsony county and the national assembly dealt with the affair of the confiscated books. ${ }^{8}$ The next case came to light almost half a century later. Although not all sources survived, we cannot consider these events as landmark cases. From the beginning of the $18^{\text {th }}$ century increasing numbers of cases came to light that involved peregrinant students being deprived of their books. In 1719 almost three thousand copies of the Bible, which was translated into Hungarian by György Komáromi Csipkés and printed in Leiden, were confiscated by the customs officers in Eperjes, not to mention the 334 books belonging to peregrinant student escorting the cargo. Most of his books included latest theological findings. From that point on regular complaints were made as a result of such procedures. ${ }^{9}$ In the middle of the $18^{\text {th }}$ century administrative measures were taken to limit the number of students who wanted to attend foreign universities. The authorities attributed the war-time or the French revolution as reasons. Obtaining passports also became challenging (also the sons of the Count Teleki family of Transylvania had to apply for it for a long time). Total prohibition

6

Weszprémi István, Magyarország és Erdély orvosainak rövid életrajza: Harmadik száz I. és II. tized, ford. Vida Tivadar, Budapest, Medicina, 1970, 69-71. Szent Biblia, az-az Istennek Ó és Uj Testamentomokban foglaltatott egész Szent Iras, magyar nyelvre fordittatott Karoli Gaspar által, es mostan hatodszor e kis formában kibotsáttatott a belgiomi académiákban tanúló magyaroknak forgolódások által, Amsterdam, Tótfalusi Kis Miklós, 1685 (RMK I 1324). Zsılınszky, Mihály, A magyar országgyúlés vallásügyi tárgyalási a reformációtól kezdve, 3, Budapest, Hornyánszky, 1893, 113, 227-228. Idézi: Monok István, A könyvbehozatal ellenőrzése a XVIII. század elején = A hagyományos világ átváltozásai: Tanulmányok a XVIII. századi magyarországi könyvtárak történetéhez, Budapest, Kossuth, Eger, Eszterházy Károly Egyetem, 2018, 37.

Monok, A könyvbehozatal..., 2018, 38-42. 
was introduced for a period of time when nobody was allowed to attend foreign universities. ${ }^{10}$ It is characteristic of the functioning of the book revision office in Pozsony that Márton Piskárkosi Szilágyi regained his books, that he purchased during his studies in Basel and Geneva with much petitioning in 1770 , i.e., 10 years later. ${ }^{11}$

\section{College libraries}

The milieu of college libraries are always more conservative than those of private collections. Uniformity and monotony are out of the question: István Monok drew attention to the fact that the aspects of Reformed school libraries in Sárospatak and Debrecen were different. In $18^{\text {th }}$ century Debrecen, the stock was dominated by books of Reformed authors and was much more homogeneous, whereas in Patak nonCalvinist (Catholic and Lutheran) books made the overall picture more colourful. Due to different tendencies in foreign university attendance Reformed theological literature was dominated by Dutch authors in Patak while there was a prevalence of Swiss authors in Debrecen. ${ }^{12}$

The 1707 catalogue of the library of the Reformed College in Marosvásárhely gives a spectacular example of backwardness. A significant portion of the 221 items in the catalogue was printed in the first half of the $17^{\text {th }}$ century or in the $16^{\text {th }}$ century (quite often before 1550). Essential grammatical, rhetorical, dialectic textbooks, standard theological works and reformed theological works of that period like Bible editions, commentaries, sermons, pious works, and polemical

10 Kosáry Domokos, Mưvelódés a XVIII. századi Magyarországon, Budapest, Akadémia, 1983, 516.

11 Pavercsik Ilona, A magyar könyvkereskedelem történetének vázlata 1800 -ig = V. Ecsedy Judit, A könyvnyomtatás Magyarországon a kézisajtó korában, 1473-1800, Budapest, Balassi, 1999, 319.

12 Monok István, Református könyvgyüjtő́k, református gyüjtemények a kora újkori Magyarországon = Kálvin hagyománya: református kulturális örökség a Duna mentén: kiállitási katalógus, szerk. FARBAKy Péter, Kiss Réka, Budapest, Budapesti Történeti Múzeum, 2009, 44-45. 


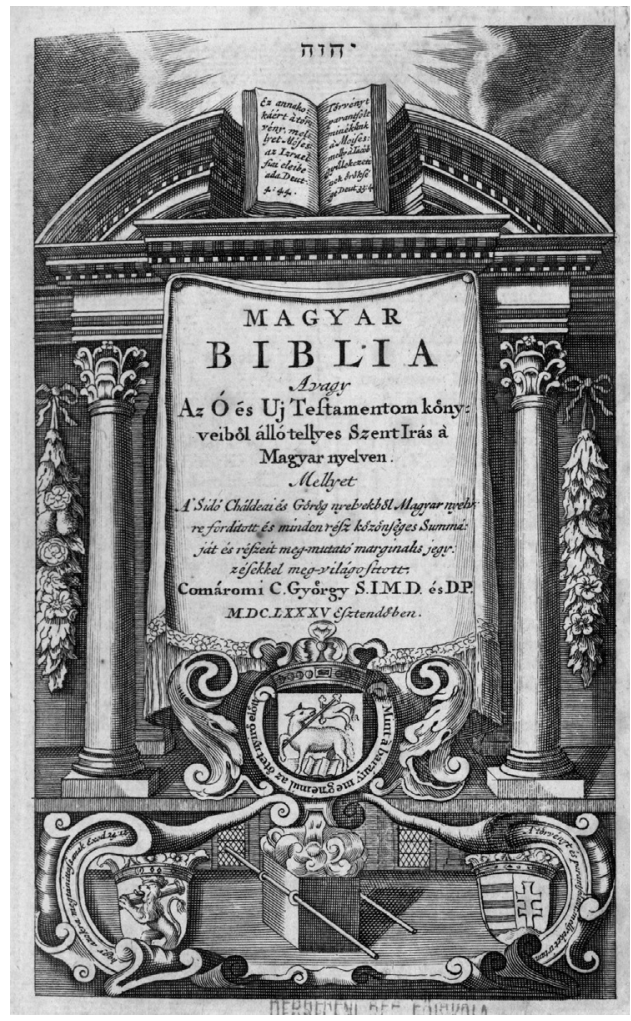

Titlepage from the Bible translated by György

Komáromi Csipkés essays were partly outdated editions. ${ }^{13}$ Even this library may have been outsized and under-utilized under contemporary conditions. The incoming rector, György Kiséri found 9 students altogether in the practically empty school in 1707. Rákóczi's insurrection (1703-1711) meant that development was not in any way the most pressing issue. In 1718 the school merged with the college of Sárospatak-Gyulafehérvár. ${ }^{14}$ The catalogues of $18^{\text {th }}$ century college libraries comprise a high number of works by John Calvin. In 1706 in the library of the Reformed College of Debrecen there were 3 copies of the Institutes of Christian Religion and 24 Bible commentaries from 1706. In 1738 a total of 48 works were registered which were written by Calvin, among them

13 Erdélyi könyvesházak, II, Kolozsvár, Marosvásárhely, Nagyenyed, Szászváros, Székelyudvarhely, JAKó Zsigmond anyaggyűjtésének felhasználásával sajtó alá rend. Monok István, Németh Noémi, Tonk Sándor, Szeged, Scriptum, 1991 (Adattár XVI-XVIII. századi szellemi mozgalmaink történetéhez, 16/2), 99_ 110.

14 Koncz József, A marosvásárhelyi evang. reform. kollegium története, Marosvásárhely, ev. ref. Kollégium, 1896, 60-62. (Klny. a Kollégium 1883_ 1888 és 1894/95. iskolai évi Értesítőiből.) 
12 copies of the Institutes of Christian Religion and 32 commentaries. The library of the Reformed College of Sárospatak, experienced numerous vicissitudes and had to move because of persecutions during the counterreformation period. This library had just half the number of books as in Debrecen in 1738: 24 volumes by Calvin: 5 copies of the Institutes of Christian Religion, 3 commentaries and 16 volumes of his „opera omnia”. The high number of copies might have been grounded by the fact that they were used for teaching purposes on the one hand; on the other hand legacies as well as donations might have accounted for it. ${ }^{15}$

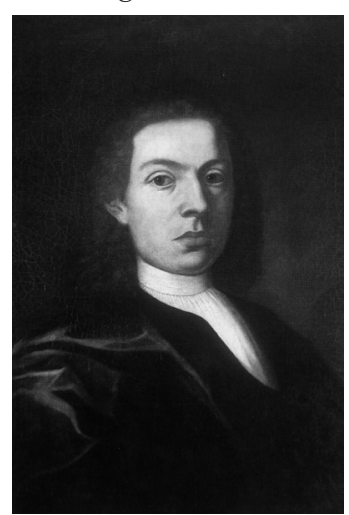

A portrait of György

Maróthi (1715-1744) Colleges also functioned as book markets. It was a habit from Nagyenyed to Debrecen to hold book auctions. In the middle of the $18^{\text {th }}$ century Professor György Maróthi brought several hundred books under the hammer after having weeding them out, and the money was used to update the stock of the College library in Debrecen. Moreover libraries of pastors were auctioned on behalf of widows. Some of these books, mainly earlier publications, were also purchased for the College library. ${ }^{16}$

The demand for hungaricums became increasingly present in the second half of the $18^{\text {th }}$ century when the appointed heads of college libraries [bibliothecae praefectus] strived to obtain publications they became aware of and related to the Hungary of the $16^{\text {th }}$ and $17^{\text {th }}$ centuries. I find the name of Professor Miklós Sinai worth accentuating. During his three-decade activity in Debrecen he was in connection with Tanulmányok Kálvinról és magyarországi jelenlétéról, szerk. G. SzABó Botond, olvasószerk. OцÁн Róbert, Debrecen, Tiszántúli Református Egyházkerület Nagykönyvtára, 2011, 131-133.

16 То́тн Béla, Maróthi György, Debrecen, Magyar Tudományos Akadémia Debreceni Akadémiai Bizottsága, 1994, 215-222; OlÁH Róbert, Book Auctions at the Reformed College of Debrecen (Megjelenés alatt - In print) 
several outstanding book collectors of his age (Péter Bod, Sámuel Dobai Székely) furthermore he closely followed publications at foreign auctions and submitted bids regularly on behalf of the College. ${ }^{17}$ A significant amount of incunabulas and antiquas (prints from the $16^{\text {th }}$ century), which are preserved even today, were purchased only in the $18^{\text {th }}$ and $19^{\text {th }}$ centuries. Sinai and his successors bought books for the college at foreign auctions, mainly in Vienna, but the sources of acquisition can sometimes be traced back to auctions in The Netherlands. In September 1776 the college bought 10 volumes at the auction of the Leidener university librarian and philologist Abraham Gronovius's books (16951775). ${ }^{18}$

Colleges often received volumes from donations and legacies. Books from legacies had typically been purchased decades earlier. In 1723, the library of the College of Debrecen received 84 volumes from the legacy of Rev. János Kecskeméti, who was a pastor in Nagykőrös. In the majority of cases these were books on theology, mainly $17^{\text {th }}$ and occasionally $16^{\text {th }}$ century editions, which included works by German (David Pareus, Johannes Piscator), Dutch (Heinrich Alting, Johannes Coccejus, Petrus Burmannus, Hermann Witsius) and Swiss (John Calvin, Rudolph Gwalther, Benedictus Aretius, Amandus Polanus, Johann Heinrich Heidegger) authors. ${ }^{19}$ The legacy of Rev. András Guthi, a pastor in Tiszafüred (1737) contained 72 items, the works of similar authors came to light besides those of Campegius Vitringa, Salomon van Till, Caspar Sibelius, Johannes Alphonsus Turretinus, Samuel

17 Feкete Csaba, G. Szabó Botond, A Kollégium Nagykönyvtára = A Debreceni Református Kollégium története, szerk. BARCzA József, Budapest, Magyarországi Református Egyház Zsinati Irodájának Sajtóosztálya, 1988, 429-436.

18 ОцÁH Róbert, Volumes from the Library of Abraham Gronovius in Debrecen = Peregrinus sum: Studies in History of Hungarian-Dutch Cultural Relations in Honour of Ferenc Postma on the Occasion of his 70 $0^{\text {th }}$ Birthday, eds. Margriet Gosker, István Monok, Budapest, Amsterdam, 2015, 149-160.

19 Partiumi könyvesházak, 1623-1730: Sárospatak, Debrecen, Szatmár, Nagybánya, Zilah, szerk. Fekete Csaba [et al.], Budapest, Szeged, Magyar Tudományos Akadémia Könyvtára, 1988 (Adattár XVI-XVIII. századi szellemi mozgalmaink történetéhez, 14), 301-303. 
Maresius, Andreas Rivetus, Johannes Buxtorf Sr. That is to say the deceased persons bought most of these books as students, and editions were catalogued that had been published 70 to 120 years earlier. ${ }^{20}$ Foreign second-hand markets sold old publications much cheaper than the more recent ones containing new information, thus, less well-to-do Hungarian students specifically bought the earlier editions and duly brought them home. ${ }^{21}$ In the $18^{\text {th }}$ century catalogues of the Reformed College Library of Debrecen notes can regularly be found on donations from students having returned from foreign universities. According to the college tradition, the grateful students having returned from abroad donated some books to their alma mater. The same thing happened to Rev. Mihály Polgári, in Mezőtúr. He was charged with high treason, and later action was taken against him. According to the old volume catalogue of the College library, which has been in use since 1738 , he made a donation of 7 volumes. ${ }^{22}$ The list of donations comprises in the first place theological (dogmatic, homiletical), historical and geographical works. ${ }^{23}$ Several similar notes in the library catalogues like „ex oris Belgicis”, „Hollandicis”, or even „exoticis” refer to the donations of returning peregrinants. ${ }^{24}$ Among present works, also by Hieronymus Zanchius, Thomas à Kempis and Hieronymus Drexel can be found. Uo., 316-319.

21 Момок István, Az olvasott örökség - hagyomány és megújulás = Kulturális örökség - társadalmi képzelet, szerk. GYörgy Péter, KIss Barbara, Monok István, Budapest, OSzK, Akadémiai, 2005, 85.

22 Lásd: Gáborjáni Szabó Botond, Polgári Mihály és Debrecen: A város szerepe egy 1752-ben felségsértési perbe fogott református lelkész ügyében $=$ „Kezembe vészem, olvasom és arról elmélkedem": Emlékkönyv Fekete Csaba születésének 75. és könyvtárosi múködésének 50. évfordulójára, szerk. G. SzABó Botond, OLÁH Róbert, Debrecen, Tisztántúli Református Egyházkerület Tudományos Gyüjteményei, 2015, 92-117.

23 Tiszántúli Református Egyházkerület Nagykönyvtára Kézirattára, R 71/8, 189v-190r.

24 OLÁH Róbert, „....redux ex oris Hollandicis...”: A németalföldi könyves müveltség emlékei a Tiszántúli Református Egyházkerület Nagykönyvtárában = Németalföld emlékei Magyarországon: Magyar-holland kapcsolatok, szerk. Bárány Attila [et al.], Debrecen, Debreceni Egyetemi Kiadó, 2017 (Loci memoriae Hungaricae, 5), 113. 


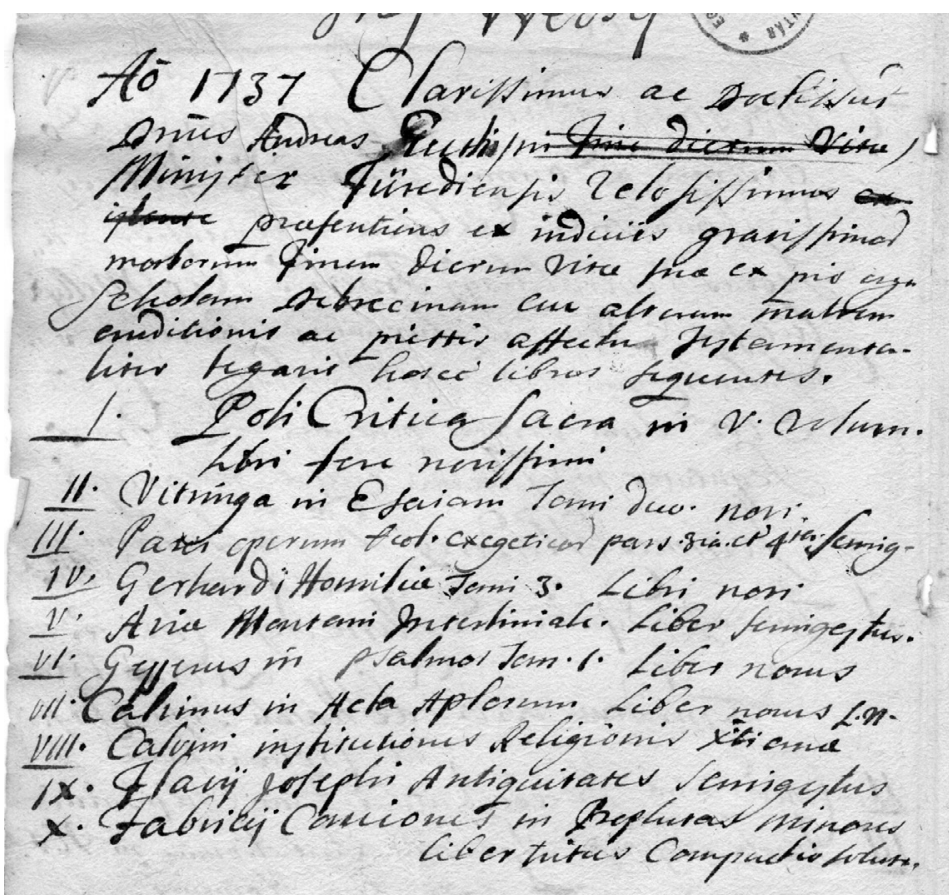

List of books from the library of András Guthi (TtRE Manuscript Collection, R 7l/5a fol. 3lv.)

Notes immortalizing the donations in the $1720^{\text {ies }}$ and $1730^{\text {ies }}$ demonstrate that new theological works were received at the former alma mater, e.g. Friedrich Adolph Lampe's works.

\section{PAstoral LIBRARIES}

Reformed intellectuals were less able to create a real theological library due to certain features of the Hungarian book-market. Encyclopaedic book collecting was much more characteristic of them: they acquired standard works on almost anything from theology to jurisprudence and medicine. They tried to set up a collection of books that they could use for a lifetime. The catalogue of the Transylvanian Bishop Mihály Tofeus contains 17 Bible editions (besides 5 Bibles in Hebrew, there are Bibles 
in Aramaic, Syrian, German, English and some in Latin and Greek). He also obtained bible-philological works regarded as modern in the middle of the $17^{\text {th }}$ century, and a significant amount of polemic publications. Apart from theological work, books could be found on the trivium, philosophy, languages, literature, history and church history, theory of the state, politics, jurisprudence, natural sciences and medicine. Finally, some non-conformist books on chiliasm, millenarism, Kabbala, black art, alchemy, which Tofeus must have purchased out of pure curiosity, generated an even more varied picture of Tofeus' library. ${ }^{25}$

The majority of the books of Rev. Péter Bod (54\%), who lived two generations later, were published before 1700. His theological collection was characterized by a higher number of Bible editions and commentaries. $16^{\text {th }}$ and $17^{\text {th }}$ century books were dominated by works of Helvetian professors and professors from Heidelberg, however, from the $17^{\text {th }}$ century onward the works written by professors from the Netherlands were in majority. Standard works by Lutheran theologians were not lacking either. ${ }^{26}$

Both Tofeus and Bod read mainly in Latin and they collected books from the same circle of authors. The follow-up of the $18^{\text {th }}$ century modern scientific literature was hindered to a great extent because Hungarian intellectuals still had Latin erudition, whereas more significant discoveries had already been published in the first place in German and French. In Debrecen regular instruction in French and German could only be introduced in 1799. It is worth mentioning that 3 years earlier a decision was made at the cost of heated debates, i.e., the language of instruction had to be Hungarian besides the partial retention of Latin. ${ }^{27}$

25 OláH Róbert, Miskolci Csulyak István és Tofeus Mihály református lelkészek könyves müveltsége (PhD dolgozat), Debrecen, Debreceni Egyetem, 2016, 103 108.

26 MоNoк István, Minister reformatus doctus: Bod Péter, és a vele kortárs református értelmiség múveltsége, Theologiai Szemle, 2012/4, 218-223.

27 Gáborjáni Szabó Botond, A Debreceni Református Kollégium a "pedagógia századában": Neveléstörténeti tanulmány XVIII. századi forrásgyüjteménnyel, Debrecen, Debreceni Református Kollégium, 1996, 84-88. 
In Hungary the language of official administration was Latin till 1844, whereas in Transylvania the Hungarian language was used for this purpose for a long time.

Sámuel Vilmányi, who died in Franeker in 1779, can be considered an exception to the rule, namely he hardly bought any $17^{\text {th }}$ century Calvinist standard works. On the contrary he purchased 7 Dutch and 40 French (mainly moral theological) volumes instead. He wanted to read scientific literature not only in Latin but also in other foreign languages to improve his professional knowledge. ${ }^{28}$

\section{John Calvin's works in the Carpathian basin}

According to the latest research, the presence of John Calvin's works can be demonstrated in various places, namely from the library of a Lutheran Saxon citizen to Catholic monastic collections. The majority of Calvin's volumes that we may come across even today came to Transylvania as late as the $17^{\text {th }}$ and $18^{\text {th }}$ centuries. Examining the spread of Calvin's main work on dogmatic we gain an understanding of several characteristic data. There was a high number of Lutherans and Unitarians among the $16^{\text {th }}$ and $17^{\text {th }}$ century owners of the Institutes of Christian Religion. The first Transylvanian owner was usually a Saxon citizen with good German connections. He was the only person from whom Calvin's main work must have reached Hungarian reformed people. Every fifth volume of the Institutes of Christian Religion could be found in Transylvania in the $18^{\text {th }}$ century. At that time all owners were Hungarian reformed people. ${ }^{29}$ The peregrinating students, who in the $18^{\text {th }}$ century brought Calvin's work hidden among cheap second-hand books, played an important role in this. Although there were also modern theological works travelling in their chests besides Calvin's works, we consider it characteristic that there was still a keen interest

28 Postma, Ferenc, Das Franeker Bücherinventar des verstorbenen ungarischen Studenten Sámuel Vilmányi, Magyar Könyvszemle, 2007/2, 233-241.

29 Ösz Sándor Előd, Bibliotheca Calviniana Transylvanica: Kora újkori Kálvinkiadások Erdélyben: Frühneuzeitliche Calvin-Ausgaben in Siebenbürgen, Kolozsvár, Erdélyi Múzeum Egyesület, Erdélyi Református Egyházkerület, 2014, 14-90. 
shown in the life-work of the Genevan reformer in the $18^{\text {th }}$ century, at the age of the so called „bloodless" counter-reformation. ${ }^{30}$

\section{The Example of the teachers of Bereg Diocese}

In 1804 the leading board of Bereg presbytery made reformed teachers, who worked on its territory, compile a list of textbooks in use. Twothirds of their collection was made up of books on theology, which is not astonishing in the case of young people who were preparing for a career as pastors and spent just a few years teaching in a rural elementary school. We have found altogether 80 authors from reformers through to Cartesians and Cocceians, from The Netherlands to the representatives of physicotheology. The most popular authors were Jean Frederic Osterwald and Benedict Pictet, representatives of the Swiss „rational orthodoxy” from the first half of the $18^{\text {th }}$ century. Most of them encapsulate the heritage of the $17^{\text {th }}$ century. By the beginning of the $19^{\text {th }}$ century they had been considered outdated. Most of the works were written in Latin or in Hungarian, books in German, mainly grammar books, were seen as exceptions. It is also possible that the teachers omitted the books from the inventory, which had to be concealed from publicity like the literature of the Enlightenment to avoid being called to account and enable them to keep their position. ${ }^{31}$

\section{Conclusion}

To conclude, I would like to emphasize two phenomena. One of them is a phenomenon that has been described in scientific literature several times. Namely until the end of the $16^{\text {th }}$ century the reception of spiritual trends by Hungarian intellectuals was continuous, however, this situation

30 ОцÁн Róbert, Kálvin müvei a kora újkori magyarországi könyvtárakban = Tanulmányok Kálvinról és magyarországi jelenlétérôl, szerk. GÁвоRJÁNi SzABó Botond, Debrecen, Tíszántúli Református Egyházkerület Nagykönyvtára, 2011, 116-148.

31 Оца́н Róbert, A beregi oskolamesterek olvasmányai a 18-19. század fordulóján = A tiszántúli református iskolák 18. századi könyvöröksége: Tanulmányok, szerk. MoNoK István, Budapest, Kossuth, Eger, Eszterházy Károly Főiskola, 2012 (Kulturális örökség), 151-238. 
underwent changes from the $17^{\text {th }}$ century onward when a growing presence of backwardness evolved. Among others the initial stage of the book market, the activity of the Catholic offices and censorship in addition to the lack of resources could have caused this decline.

Not all aspects of this process were necessarily destructive, e.g. the Saxons in Transylvania preferred the use of $16^{\text {th }}$ and $17^{\text {th }}$ century orthodox Lutheran works to those of irenical and Calvinist authors in order to settle internal debates and keep the community together. ${ }^{32}$ Hungarian and Transylvanian reformed believers returned to Calvin's doctrines during the counter-reformation, which was characterized by countless aggressive actions supported by the Catholic state power. In the middle of the $18^{\text {th }}$ century the biography of the Genevan reformer written by Beza was translated into Hungarian for the first time ${ }^{33}$ and the massacre on St. Bartholomew's night (1572) with the figure of Admiral Gaspard de Coligny. Moreover the stories of Protestant martyrs who lived centuries before were actualized, thus, setting an example for persecuted reformed people. ${ }^{34}$

Besides the counter-reformation the reformed pastors also had to face the spread of deism and atheism, against which numerous polemical essays were written in the second half of the $18^{\text {th }}$ century. Hard-pressed reformed people must have turned to old pieces of reading to use them as a tool in their struggle for their survival. According to István Monok, archaization might have been a modern and effective reaction at the right moment. ${ }^{35}$

32 Monok István, Ortodoxia és humanitás, Iskolakultúra, 1996/9, 31-32.

33 See: Huszti László, Calvinus János élete, szerk. Tóтн Zsombor, Budapest, rec. iti, 2019, 18-22.

34 ОцÁн Róbert, A Parisi lakodalom (1572): Egy 18. századi elbeszélés a Szent Bertalan éjról, Studia Litteraria, 2012/3-4; Protestáns mártirológia a kora újkorban, szerk. Csorba Dávid [et al.], Debrecen, Debreceni Egyetem Magyar Irodalom- és Kultúratudományi Intézete, 2013, 232-258.

35 See: Monok István, What Makes a Library in Hungary or Transylvania Modern in the Early Modern Age?: Some Aspects of Assessment = Ein Land mit Eigenschaften: Sprache, Literatur und Kultur in Ungarn in transnationalen Kontexten: Zentraleuropaische Studien für Andrea Seidler, Wien, Praesens Verlag, 2015, 131-140. 
LES BIBLIOTHÈQUES ET L'ÉCONOMIE DES CONNAISSANCES Bibliotheken und die ÖKonomie des Wissens

$$
145^{\circ}-185^{\circ}
$$

Colloque international - Internationale Tagung 9-13 avril/April 2019 Sárospatak (Hongrie/Ungarn)

Édité par

Frédéric Barbier, István Monok et Andrea Seidler 


\section{L'Europe en réseaux}

Contribution à l'histoire de la culture écrite 1650-1918

Vernetztes Europa

Beiträge zur Kulturgeschichte des Buchwesens 1650-1918

Édité par

Frédéric Barbier, Marie-Elisabeth Ducreux, Matthias Middell, István Monok, Éva Ringh, Martin Svatoš

Volume VIII

École pratique des hautes études, Paris

École des hautes études en sciences sociales, Paris

Centre des hautes études, Leipzig

Bibliothèque nationale Széchényi, Budapest

Bibliothèque et centre d'information de l'Académie hongroise des sciences, Budapest 
LeS BIBLIOTHÈQUeS ET L'ÉCONOMIE DES CONNAISSANCES BibliotheKen und die ÖKonomie des Wissens

$$
145^{\circ}-185^{\circ}
$$

Colloque international - Internationale Tagung 9-13 avril/April 2019 Sárospatak (Hongrie/Ungarn)

Édité par

Frédéric Barbier, István Monok et Andrea Seidler

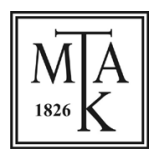

Magyar Tudományos Akadémia Könyvtár és Információs Központ Budapest 2020 
Mise en page

Viktória Vas

ISBN 978-963-7451-57-7

DOI 10.36820/SAROSPATAK.2020 
Préface

István MoNOK

Bibliothecae mutantur - Quare, quemadmodum et quid attinet?

Transformations de la composition thématique

des bibliothèques du Royaume de Hongrie aux $\mathrm{XV}^{\mathrm{E}}-\mathrm{XVI} \mathrm{I}^{\mathrm{e}}$ siècles....11

Marianne CARbonnier-Burkard

Les bibliothèques des Églises réformées françaises au XVII siècle.... 30

Max Engammare

De la bibliothèque de l'Académie de Calvin (1570) a la bibliothèque de l'Académie de Bèze (1612) à travers leur catalogue: Continuités et ruptures jusqu'au troisième catalogue de 1620........... 57

Róbert OLÁ́

Obsolescent Reformed Libraries in the seventeenth and eighteenth Century Carpathian Basin

Ádám Hegri

Moderner Zeitgeist - veraltete Lesestoffe. Bibliotheken reformierten Pfarrer um die Wende des 18. zum

19. Jahrhunderts im Königreich Ungarn

Petr MAšEK

Zierotin Library in Velké Losiny in Sixteenth and Seventeenth century. 136

Detlef HABERLAND

Schlesische Bibliotheken Zeichen der intellektuellen Vielfalt einer zentralen Bildungsregion in Europa 146

Thomas WaLLNIG

Sebastian Tengnagel und Johann Seyfried - Österreichische

Geschichtsschreibung zwischen Späthumanismus und

Gegenreformation 
Elisabeth EngL-Ursula RautenBerg

Christoph Jacob Trew - Bibliothek und Sammeln in der Gelehrtengemeinschaft der ersten Hälfte des 18. Jahrhunderts.

Helwi BLOM

Philosophie ou Commerce?

L'évolution des systèmes de classement bibliographique dans les catalogues de bibliothèques privées publies en France au XVIII ${ }^{\mathrm{e}}$ siècle.

Maria Luisa López-VIDrIero Abelló

Les meubles de la connaissance: façons de devenir sage à prix fixe.

Frédéric BARbier

Distinction, récréation, identité: la trajectoire des « romans» en France sous d'Ancien Régime.

\section{Andrea SeIdler}

Die praktische Bedeutung ungarischer Sammlungen und Bibliotheken für führende Gelehrte des Königreichs Ungarn im späten 18. Jahrhundert am Beispiel des Jesuiten Georg Pray (1723-1801).

\section{Olga Granasztói}

Se divertir: les enseignements de la bibliothèque d'une femme aristocrate hongroise à la fin du XVIII siècle

Christophe Didier

La naissance du théâtre „des boulevards”, ou Comment la banlieue entre en bibliothèque (1780-1830).

\section{Andrea De Pasquale}

La nascita delle riserve di libri antichi in Italia

Index des noms de personne et de lieu..... 